Dr VLADIMIR LJ. CVETKOVIĆ, viši naučni saradnik

Institut za noviju istoriju Srbije

Beograd, Republika Srbija

UDK 94:327.323.3(497.1)"1948"(093.2)

cvetkovicv@yahoo.com

originalan naučni rad / original scientific paper

primljeno / received: 28. 8. 2020.

prihvaćeno / accepted: 20. 11. 2020.

https://doi.org/10.29362/ist20veka.2021.1.cve.99-114

\title{
DVOVLASNIČKI REŽIM I STANJE NA JUGOSLOVENSKO-RUMUNSKOJ GRANICI 1945-1948.*
}

APSTRAKT: Članak, napisan na osnovu jugoslovenskih arhivskih izvora i relevantne literature, predstavlja analizu stanja na jugoslovenskorumunskoj granici od završetka Drugog svetskog rata do naglog pogoršanja odnosa dveju susednih zemalja posle objavljivanja Rezolucije Informbiroa juna 1948. godine. Prateći stanje bezbednosti na granici, pogranične incidente $i$ funkcionisanje dvovlasničkog režima moguće je uočiti stav i politiku Jugoslavije prema Rumuniji i dešavanjima na njenoj političkoj sceni u periodu njenog preobražaja iz višestranačke monarhije u jednopartijsku republiku sovjetskog tipa.

KLJUČNE REČI: Jugoslavija, Rumunija, dvovlasnički režim, pogranični incidenti, sovjetizacija

Završetkom Drugog svetskog rata u proleće 1945. godine jugoslovensko-rumunska granica, koja tokom nemačke okupacije Jugoslavije u skladu sa vojnim potrebama okupatora gotovo da nije ni postojala, ponovo postaje međudržavna granica u pravom smislu te reči. Granična linija koja je određena na Mirovnoj konferenciji u Versaju posle Prvog svetskog rata kao granica između Kraljevine Srba, Hrvata i Slovenaca i Kraljevine Rumunije, koje same nisu mogle da se o njoj dogovore, bila je rezultat kompromisa koji su diktirale velike sile pobednice. ${ }^{1}$ Kao zakasneli odraz spora oko razgraničenja dveju susednih

\footnotetext{
* Rad je deo projekta Srbi i Srbija u jugoslovenskom i međunarodnom kontekstu. Unutrašnji razvitak $i$ položaj u evropskoj/svetskoj zajednici (br. 47027), koji finansira Ministarstvo prosvete, nauke i tehnološkog razvoja Republike Srbije.

${ }^{1}$ Više o tome u: Andrej Mitrović, Razgraničenje Jugoslavije sa Mađarskom i Rumunijom: 19191920: prilog proučavanja jugoslovenske politike na Konferenciji mira u Parizu (Novi Sad: Institut za izučavanje istorije Vojvodine, 1975); Andrej Mitrović, Jugoslavija na Konferenciji mira: 1919-1920 (Beograd: Zavod za izdavanje udžbenika Socijalističke Republike Srbije, 1969); Богдан Кризман, „Питање граница Војводине на Паришкој међународној конференцији 1919. године (дипломатско-хисторијска скица)“, Зборник Матище српске за друштвене
} 
zemalja i kao posledica činjenice da je Rumunija bila poražena u ratu i tek trebalo da pregovara o mirovnom ugovoru sa saveznicima, u jesen 1944. i tokom 1945. godine kod pripadnika srpske manjine u Rumuniji i jednog broja jugoslovenskih zvaničnika postojala je ideja o eventualnoj korekciji granice između dveju zemalja koja je, međutim, ostala na nivou ideje pošto Jugoslavija nikada u zvaničnoj formi tako nešto nije ni predlagala ni zahtevala, ne samo od Rumunije već ni od saveznika. ${ }^{2}$ U novim spoljnopolitičkim okolnostima - uz prisustvo Crvene armije koje je za Rumuniju u najmanju ruku bilo neželjeno i u uslovima korenitih političkih i društvenih promena koje su obe susedne zemlje gurale u pravcu izgradnje društva po sovjetskom modelu - na jugoslovensko-rumunskoj granici bilo je uočljivo da dve zemlje nisu tom cilju pristupale sa podjednakim elanom ili sa istom motivacijom. Dok je u Jugoslaviji predvođenoj Komunističkom partijom Jugoslavije koja je iza sebe imala autohtonu revoluciju i oreol borca protiv fašističkog okupatora proces sovjetizacije bio brz i efikasan, u Rumuniji je malobrojna Komunistička partija Rumunije, naravno uz presudnu pomoć Sovjeta, imala znatno teži zadatak da savlada otpor u vidu izrazitog antiruskog i antikomunističkog raspoloženja koje je postojalo u vojsci, policiji, administrativnom aparatu i najširim slojevima stanovništva. ${ }^{3}$ Stanje na jugoslovensko-rumunskoj granici od 1945. do 1948. godine svedočilo je o odnosu rumunskih vlasti prema problemima koji su se pojavljivali kao prirodna posledica postojanja granice na određenom prostoru kao i o njihovom odnosu prema saradnji sa jugoslovenskim vlastima. Takođe, moguće ga je posmatrati i kao odraz oštre unutrašnje borbe u Rumuniji koja je okončana pobedom sovjetskog modela i uspostavljanjem ,narodne demokratije“ u toj zemlji.

Prisustvo sovjetske Crvene armije koja je u Jugoslaviji boravila u jesen 1944. godine samo onoliko koliko je to bilo potrebno zbog ratnih operacija, a u Rumuniji još godinama posle Drugog svetskog rata, bilo je primetno i na grani-

науке, бр. 24, (1959); Gligor Popi, Jugoslovensko-rumunski odnosi 1918-1941 (Novi Sad: Institut za istoriju Filozofskog fakulteta u Novom Sadu, 1984); Бранко Петрановић, „Питање граница Југославије према Мађарској и Румунији и југословенских мањина у Мађарској и Румунији после Првог и Другог светског рата (историјска паралела)“, Историјски записи, XXXIX (LIX), бр. 3, (1986).

${ }^{2}$ Više o tome u: Б. Петрановић, „Питање граница Југославије према Мађарској и Румунији...”, 114-116; Андреј Милин, Миодраг Милин и Цветко Михајлов, Срби у Румунији за време комунизма. Звучни архив и приручник о страдању (Темишвар: Савез Срба у Румунији, 2011); Миодраг Милин и Андреј Милин, Срби из Румуније и југословенско-румунски односи. Прилог и грађа (1944-1948) (Вршац: Виша школа за образовање васпитача, Темишвар: Универзитет „Banatului“, 2004); Владимир Љ. Цветковић, „Црвена армија на Дунаву, ослобођење Београда и тежње Срба из Румуније ка присаједињењу Југославији 1944-1945.“, у: Ослобођење Београда 1944. године, уредник Александар Животић (Београд: Институт за новију историју Србије, 2010), 168-184; Павле Стојанов, Југословенска национална мағина у Румунији, (Београд: Култура, 1953).

${ }^{3}$ Više o sovjetizaciji Rumunije posle Drugog svetskog rata u: Șerban Rădulescu-Zoner, Daniela Bușe, Beatrice Marinescu, Instaurarea totalitarismului comunist în România (București: Cavallioti, 2002); Gheorghe I. Ionița, Istoria românilor - de la 23 august 1944 până în prezent (București: Editura Universității din București, 2001); Dennis Deletant, Romania under Communist Rule (Bucharest: Civic Academy Foundation, 2006). 
ci. Njihov status savezničke okupacione sile u Rumuniji koja tamo nije bila rado viđena a, sa druge strane, bratske i novim vlastima ideološki bliske vojske u Jugoslaviji, dovodio je do problema i nesporazuma na jugoslovenskorumunskoj granici prevashodno stoga što se Sovjeti nisu uvek obazirali na okolnosti. U leto 1945. godine rumunsko Ministarstvo inostranih poslova žalilo se da jugoslovenski građani bespravno seku šumu na rumunskoj adi Ostrovu Mare, nizvodno od Turn Severina. Prema tim navodima, postojala je opasnost da državni šumski kompleks od 200 hektara bude potpuno uništen bespravnom sečom i to uz napade na šumare i stražu koja je to pokušavala da spreči. ${ }^{4}$ Jugoslovenske vlasti su, međutim, ubrzo utvrdile da su šumu na Ostrovu Mare i ranije i u tom trenutku sekli jedino vojnici Crvene armije koji su na obodu šume, na samoj obali, gradili stanove a sav otpadni materijal spaljivali ili bacali u Dunav u nastojanju da raščiste teren. ${ }^{5}$ Iako je u ovom slučaju šteta bila naneta rumunskoj strani, dešavalo se da prisustvo crvenoarmejaca na rumunskoj obali Dunava nanese štetu i na jugoslovenskoj obali reke. U jesen iste godine, jugoslovenska policija je u okolini Kladova presrela trojicu sovjetskih vojnika koji su došli iz Rumunije i u selu Kostol oduzeli svinju, prase, dve ovce i dve patke koje su pokušali da prebace u Rumuniju, u čemu su sprečeni. ${ }^{6}$ Iako su se sovjetske nadležne komande trudile da što kaznama što preventivnim delovanjem spreče ovakve ispade svojih pripadnika, ${ }^{7}$ slični slučajevi su se događali i početkom 1946. godine, s tom razlikom što ovog puta nije bila reč o pljački već o dobro organizovanom i uhodanom krijumčarskom kanalu koji su održavali crvenoarmejci iz Rumunije. U grupama koje su brojale i do deset vojnika, oni su iz Rumunije donosili so, gumu i odeću koje su sa čamaca, na otvorenom delu reke, razmenjivali za svinje, mast i sir koje su donosili seljani iz okolnih sela Vinci, Brnjica i Dobra. ${ }^{8}$ Za jugoslovenske pogranične službe izazov je bio kako ovu praksu sprečiti a da ne dođe do „neželjenog sukoba“ pogotovo imajući u vidu da su crvenoarmejci po pravilu bili naoružani i, najčešće, u alkoholisanom stanju. ${ }^{9}$ Rešenje je, na kraju, nađeno u češćem patroliranju tim sektorom Dunava i zabrani lokalnom stanovništvu da sa crvenoarmejcima „trguju“ na ovakav ili sličan način.

Život u blizini jugoslovensko-rumunske granice, u vreme još nesređenih prilika neposredno po okončanju Drugog svetskog rata, bio je skopčan sa

\footnotetext{
${ }^{4}$ Diplomatski arhiv Ministarstva spoljnih poslova Republike Srbije (DA MSP), Strogo poverljiva arhiva (SPA), 1945-1946, fasc. 11, br. 11, Izveštaj predstavnika DFJ u Bukureštu Nikole Grulovića pomoćniku ministra inostranih poslova DFJ Vladimiru Velebitu, 15. 6. 1945, 2-3.

${ }^{5}$ DA MSP, Poverljiva arhiva (PA), Rumunija, 1945, fasc. 27, dos. 25, sign. 4482, Dopis načelnika političkog odeljenja MIP-a DFJ jugoslovenskom Predstavništvu u Bukureštu, 22. 9. 1945.

${ }^{6}$ DA MSP, PA, Jugoslavija, 1945, fasc. 21, dos. 7, sign. 5875, Dopis pomoćnika ministra unutrašnjih poslova M. Radovića Ministarstvu inostranih poslova DFJ, 7. 11. 1945.

7 Алексеј Тимофејев, „Искуство сучељавања: Црвеноармејци и становништво Србије“, у: Ослобођење Београда 1944, 219-220.

${ }^{8}$ Arhiv Jugoslavije (AJ), fond 50, Ministarstvo trgovine i snabdevanja DFJ, fascikla 64, arhivska jedinica 138, Dopis pomoćnika ministra unutrašnjih poslova FNRJ M. Radovića - Predsedništvu Vlade, Ministarstvu inostranih poslova i Ministarstvu odbrane FNRJ, br. 43, 19. 1. 1946.

${ }^{9}$ Isto.
} 
nesigurnošću i rizicima budući da je krijumčarima granica često služila kao brana i zaštita od policije jedne ili druge države. Ona je omogućavala da se povremeno organizuju pljačkaški upadi nakon kojih bi cela grupa jednostavno nestala sa druge strane granice. Jedan takav upad pljačkaške grupe iz Rumunije, sastavljene od 12 do 15 ljudi, dogodio se u noći 9/10. jula 1945. u okolini Srpske Crnje kada je u mestu Klarija (danas Radojevo) oteto 18 konja, ždrebe, jedna kola, mnoštvo krevetnine i odeće, a nekoliko muškaraca i dve žene pretučeno. ${ }^{10} \mathrm{U}$ ovom slučaju jugoslovenske vlasti su bile ubeđene da su za napad odgovorni „ostaci izdajničkih bandi“ koje su prebegle na teritoriju Rumunije i tamo se skrivale. ${ }^{11}$ Međutim, upadi naoružanih konjokradica i pljačkaša iz Rumunije koji nisu imali nikakve veze sa ,izdajničkim bandama“ iz Jugoslavije dešavali su se i kasnije. U noći 22/23. aprila 1946. u selu Hajfeld (danas Novi Kozarci) kod Srpske Crnje ukradeno je i preko granice prebačeno osam konja, a 4. maja iste godine u Mokrin je upala grupa od 20 do 30 naoružanih ljudi koji su pljačkali kuće, maltretirali stanovništvo i potom oteli 10 konja i jedno ždrebe koje su odveli u Rumuniju. ${ }^{12}$ Posle ovih ponovljenih upada, jugoslovenske vlasti su 22. juna Rumuniji uputile protestnu notu zahtevajući od nje da sprovede istragu, kazni krivce i vrati ukradene konje. Početkom septembra rumunska strana je odgovorila na notu ali, nažalost, samo konstatacijom da je istragu sprovela ali da krivce i ukradene konje nije pronašla. ${ }^{13}$

Dok je jednom broju kriminalaca jugoslovensko-rumunska granica prvih godina posle Drugog svetskog rata pružala priliku za ,zaradu“, za neke druge je bila prilika da umaknu od pravde. U leto 1947. godine, grupa od 15 ljudi je kod sela Kladušnica u blizini Kladova pokušala da iz Rumunije usred bela dana prepliva u Jugoslaviju, u čemu ih je omeo prolazak velikog sovjetskog broda koji je podigao talase. Samo jedan od njih uspeo je da se dokopa jugoslovenske obale i vlastima prizna de je u pitanju bila grupa zatvorenika (što političkih što običnih kriminalaca) koji su pobegli iz rumunskih zatvora. ${ }^{14}$ Bilo bi, međutim, pogrešno zaključiti da je poroznost jugoslovensko-rumunske granice, koja je u periodu od 1945. do 1948. godine bila veća nego što bi se očekivalo, pogodovala samo pljačkašima, kriminalcima i krijumčarima. Lokalno stanovništvo, koje inače ne bi bilo u prilici da često prelazi granicu, u takvim okolnostima je moglo lakše i intenzivnije da komunicira sa svojim nekadašnjim prirodnim centrima kojima je gravitiralo pre uspostavljanja granične linije, što je bilo naročito važno za srpsko stanovništvo Banatske Klisure koje je gravitiralo ka Beloj Crkvi. U jesen 1945. godine,

${ }^{10}$ AJ, 50-64-138, Prepis telegrama Sreskog narodnog odbora iz Srpske Crnje upućenog Ministarstvu unutrašnjih poslova DFJ, br. 68/45, 11. 7. 1945.

${ }^{11}$ AJ, 50-64-138, Dopis pomoćnika ministra unutrašnjih poslova DFJ M. Radovića - Generalnom sekretaru Predsedništva ministarskog saveta DFJ, br. 732, 11. 7. 1945.

${ }^{12}$ DA MSP, PA, Rumunija, 1946, fasc. 76, dos. 11, Dopis Ministarstva inostranih poslova FNRJ - Ambasadi FNRJ u Bukureštu, br. 6373, 7. 6. 1946.

${ }^{13}$ DA MSP, PA, Rumunija, 1946, fasc. 76, dos. 11, Dopis Ministarstva inostranih poslova FNRJ - Ministarstvu unutrašnjih poslova FNRJ, br. 10501, 5. 9. 1946.

${ }^{14}$ DA MSP, PA, Rumunija, 1947, fasc. 103, dos. 4, Dopis načelnika štaba KNOJ-a Draga Đukanovića - Ministarstvu inostranih poslova FNRJ, br. 413353, 18. 7. 1947. 
Okružni narodni odbor iz Pančeva uspeo je da preko Ministarstva unutrašnjih poslova i Ministarstva prosvete isposluje za đake srpske nacionalnosti iz Banatske Klisure, koji su bili rumunski državljani, stalne dozvole za prelazak granice radi upisa i pohađanja gimnazije i zanatskih škola u Beloj Crkvi. ${ }^{15} \mathrm{~S}$ druge strane, jugoslovenske vlasti su bile voljne da svojim građanima iz Kladova i okoline kojima je bila hitno potrebna lekarska pomoć a nisu bili u stanju da izdrže put do Negotina ili Zaječara, dozvole da prelaze u Rumuniju radi lečenja u Turn Severinu, ukoliko su to oni želeli. ${ }^{16}$

Pored problema koje su povremeno izazivali crvenoarmejci, krijumčari i pljačkaši jugoslovensko-rumunska granica je u periodu 1945-1948. godine bila i poprište klasičnih pograničnih incidenata u kojima su akteri uglavnom bili vojni organi obeju susednih država. Tome je, kao i problemima sa krijumčarima i drugim kriminalcima, pogodovala relativno slaba obezbeđenost granice sa jugoslovenske strane, naročito neposredno po okončanju Drugog svetskog rata. Zadatak obezbeđenja državnih granica u Jugoslaviji bio je poveren Korpusu narodne odbrane Jugoslavije (KNOJ) osnovanom još avgusta 1944. s tim da je on, usled spoljnopolitičkih okolnosti, delovao u dva različita granična režima - jednom prema Austriji, Italiji, Slobodnoj teritoriji Trsta (STT) i Grčkoj i drugom, prema Albaniji, Bugarskoj, Rumuniji i Mađarskoj. ${ }^{17}$ Granični režim prema drugoj grupi zemalja bio je neuporedivo labaviji jer su na granici prema Albaniji i Bugarskoj granične jedinice bile stacionirane samo na graničnim prelazima dok je brojno stanje 7. divizije KNOJ-a (Vojvođanske), koja je obezbeđivala granicu prema Mađarskoj i Rumuniji, bilo smanjeno. ${ }^{18}$ Malobrojnost jedinica je bila samo jedan od problema sa kojima se KNOJ susretao. Kvalitet njegovih pripadnika i njihova obuka za službu na granici često nisu bili odgovarajući što je u pojedinim slučajevima dovodilo jugoslovenske vlasti u nelagodan položaj prema Rumuniji i tamošnjoj Savezničkoj kontrolnoj komisiji (SKK), budući da je od njihovih podataka o incidentima zavisio stav države. O tome najbolje svedoči incident koji se dogodio 8. septembra 1945. u blizini mesta Jaša Tomić. U izveštaju nadležne čete KNOJ-a navedeno je da je tada uočena grupa od 10 krijumčara koja se, koristeći kukuruzišta, brzo povukla na rumunsku teritoriju sa koje se ubrzo pojavio rumunski vojnik koji je na poziv jugoslovenskih graničara tvrdio da su primećeni civili, u stvari, rumunska patrola. ${ }^{19} \mathrm{U}$ međuvremenu, jugoslovenski vojnici su primetili

\footnotetext{
${ }^{15}$ AJ, fond 313, Ministarstvo prosvete Vlade FNRJ, fascikla 5, arhivska jedinica 11, Dopis Ministarstva unutrašnjih poslova DFJ - Ministarstvu prosvete DFJ, br. 4125, 14. 9. 1945; Dopis Ministarstva prosvete DFJ - Ministarstvu unutrašnjih poslova DFJ, br. 4162, 19. 9. 1945.

${ }^{16}$ AJ, 50-64-138, Dopis pomoćnika ministra unutrašnjih poslova Veljka Mićunovića - Predsedništvu vlade FNRJ, br. 12786, 15. 8. 1946; AJ, 50-64-139, Dopis generalnog sekretara Predsedništva vlade FNRJ Mitra Bakića - Ministarstvu unutrašnjih poslova FNRJ, br. 2527, 23. 8. 1946.

17 Дмитар Тасић, „Организација граничне службе у југословенским оружаним снагама од краја Другог светског рата до резолуције Информбироа 1948. године“, Војноисторијски гласник, бр. 1, (2014), 234-236.

${ }^{18}$ Исто, 236, 238

${ }^{19}$ DA MSP, PA, Rumunija, 1946, fasc. 76, dos. 11, Dopis Ministarstva inostranih poslova DFJ Predstavništvu DFJ u Bukureštu, br. 4391, 19. 9. 1945.
} 
prokrijumčareno bure masne sode na svojoj teritoriji posle čega je rumunski vojnik, a potom i ostali iz njihove patrole, otvorio vatru ka jugoslovenskoj strani, na šta ona nije odgovorila pošto su se rumunski graničari brzo povukli u dubinu svoje teritorije. Iz ovog događaja organi KNOJ-a su zaključili da rumunski granični organi pomažu, pa čak i aktivno učestvuju u krijumčarenju, što je dovelo do intervencije jugoslovenskog diplomatskog predstavništva kod SKK. ${ }^{20}$ Nekoliko meseci kasnije, međutim, posle zajedničke istrage, jugoslovensko predstavništvo je od SKK dobilo originalni zapisnik u kome su jugoslovenski graničari isti događaj predstavili drugačije, što je u potpunosti dezavuisalo Ministarstvo inostranih poslova u Beogradu. ${ }^{21}$ Iz Predstavništva FNRJ u Bukureštu je zato traženo da nadležni u KNOJ-u upoznaju potčinjene sa procedurama sastavljanja izveštaja o incidentima, jer nije bilo „ni malo zgodno“ da izveštaji sa takvim tvrdnjama ulaze u diplomatsku prepisku i nanose štetu interesima zemlje. ${ }^{22}$

Jedan od najčešćih načina na koji je remećen mir na graničnoj liniji između Jugoslavije i Rumunije bilo je otvaranje vatre sa rumunske na jugoslovensku stranu, o čemu postoji mnoštvo primera. Na jugoslovensku patrolu koja se kretala obalom Dunava 12 kilometara uzvodno od Golupca 4. aprila 1946. rumunski graničari su, sa svoje obale, ispalili 16 metaka na šta jugoslovenska patrola nije reagovala. Samo nekoliko dana kasnije, 12. aprila, na istom mestu ispaljeno je šest hitaca na jednog jugoslovenskog bolničara posle čega je Ministarstvo inostranih poslova FNRJ tražilo od ambasade u Bukureštu da nadležnima skrene pažnju na neprihvatljivo ponašanje rumunskih graničara. ${ }^{23}$ Odgovarajući na ove navode, rumunsko Ministarstvo inostranih poslova je pobijalo odgovornost za incidente tvrdeći da u to vreme na tim mestima nije bila prisutna nikakva rumunska patrola niti je bio primećen utrošak municije kod patrola koje su tog dana bile na dužnosti. Štaviše, oni su tvrdili da su hici najverovatnije mogli doći sa nekog broda koji je u tom trenutku plovio Dunavom, predlažući da se jugoslovenske vlasti ubuduće obrate najbližoj komandi rumunske granične straže kako bi se istraga sprovela brzo a incident rešio na obostrano zadovoljstvo. ${ }^{24} \mathrm{U}$ međuvremenu, incidenti slični ovima događali su se i dalje. Tako je 25. juna iste godine ispaljeno sa rumunske strane nekoliko metaka na jugoslovensku teritoriju kod Velikog Gradišta, 18. septembra kod sela Ljubičevca, 21. novembra 12 do 15 metaka ispaljeno je na jugoslovenskog stražara na karauli kod Radujevca, a dan kasnije i dva metka na samu karaulu. ${ }^{25}$ I naredne, 1947.

\footnotetext{
${ }^{20}$ Isto.

${ }^{21}$ DA MSP, PA, Rumunija, 1946, fasc. 76, dos. 11, Dopis Predstavništva FNRJ u Bukureštu Ministarstvu inostranih poslova u Beogradu, br. 1889, 7. 2. 1946.

${ }^{22}$ Isto.

${ }^{23}$ DA MSP, PA, Rumunija, 1946, fasc. 76, dos. 11, Dopis v. d. pomoćnika načelnika I regionalnog odeljenja MIP FNRJ Veliše Gošovića - ambasadi u Bukureštu, br. 5669, 21. 5. 1946.

${ }^{24}$ DA MSP, PA, Rumunija, 1946, fasc. 76, dos. 11, Dopis v. d. pomoćnika načelnika I regionalnog odeljenja MIP FNRJ Veliše Gošovića - Ministarstvu unutrašnjih poslova FNRJ, br. 8484, 20.7. 1946.

${ }^{25}$ DA MSP, PA, Rumunija, 1947, fasc. 103, dos. 4, Dopis v. d. pomoćnika načelnika I regionalnog odeljenja MIP FNRJ Draga Govorušića - ambasadi u Bukureštu, br. 44750, 19. 3. 1947.
} 
godine događali su se slični incidenti: 15. januara je ispaljen svetleći metak koji je pao blizu stražara na karauli Malo Golubinje, a 12. februara sa rumunske obale su ispaljena dva hica koja su preletela parobrodarsku stanicu u Donjem Milanovcu. Iako jugoslovenske vlasti sve ove incidente nisu označavale kao namernu provokaciju već kao izraz samovolje nedovoljno kontrolisanih rumunskih pograničnih organa, ponovo su, zbog mogućnosti da oni dovedu do težih posledica, od svoje ambasade u Bukureštu zahtevale da intervenišu kod rumunskih vlasti ne bi li se takvi nemili događaji predupredili. ${ }^{26}$

Osim čestog otvaranja vatre na jugoslovensku stranu granice, dešavalo se i da rumunski graničari prelaze na jugoslovensku teritoriju. Četvoricu naoružanih rumunskih vojnika koji su prešli na jugoslovensku teritoriju uhvatile su jedinice KNOJ-a 5. novembra 1946. na raskrsnici puteva za Jabukovac, Brzu Palanku i Negotin. ${ }^{27}$ Krajem januara 1947. dvojica naoružanih rumunskih graničara uhvaćena su kod sela Vatin, u blizini Vršca. Oni su tvrdili da su na jugoslovensku teritoriju zalutali zbog magle i snega koji je zatrpao njihovu patrolnu stazu, što im nije pomoglo da izbegnu hapšenje i predaju organima Odeljenja državne bezbednosti (UDB) u Vršcu. ${ }^{28} \mathrm{O}$ ozbiljnosti ovakvih incidenata najbolje svedoči činjenica da su ova dvojica rumunskih graničara, i pored intervencija Rumunije, početkom aprila još uvek bila u jugoslovenskom zatvoru. ${ }^{29}$ Osim graničara, krijumčara, pljačkaša i zatvorskih begunaca, jugoslovenskorumunsku granicu su neovlašćeno prelazili i avioni. Incidenti u vazdušnom prostoru u rejonu granice bili su česti, ali najčešće i nerazjašnjeni. Zbog visine na kojoj su leteli, avioni su teško mogli biti identifikovani. Dva takva nepoznata aviona doletela su 19. oktobra 1946. iz Rumunije, nadletela Brzu Palanku i odletela u unutrašnjost Jugoslavije. ${ }^{30}$ Dva meseca kasnije, 17. decembra, grupa od čak 25 do 30 aviona je u 9 časova pravcem Kikinda - Velika Teremija (rum. Teremia Mare) odletela u Rumuniju da bi se pola sata kasnije, sada pravcem Velika Teremija - Kikinda, osam aviona vratilo i odletelo u unutrašnjost Jugoslavije. ${ }^{31}$ Zbog visine preleta od 1.600 metara ni ovog puta nije mogao da bude utvrđen ni tip letelica ni njihova pripadnost.

Nažalost, bilo je i incidenata sa najtežim posledicama. Jugoslovenski ribar Jovan Firnjatov koji je ribario u blizini rumunske ade Ostrovo Mare ubijen je hicima rumunskih graničara 15. januara $1946 .{ }^{32} \mathrm{U}$ jesen naredne, 1947. godi-

26 Isto.

${ }^{27}$ DA MSP, PA, Jugoslavija, 1946, fasc. 47, dos. 15, Izveštaj II odeljenja Generalštaba Jugoslovenske armije o incidentima i prekršajima, br. 14116, 27. 11. 1946.

28 DA MSP, PA, Rumunija, 1947, fasc. 103, dos. 4, Dopis pomoćnika načelnika I regionalnog odeljenja MIP FNRJ Blagoja Hadži-Panzova - Ministarstvu unutrašnjih poslova FNRJ, br. 45957, 8. 4. 1947.

29 Isto.

${ }^{30}$ DA MSP, PA, Jugoslavija, 1946, fasc. 47, dos. 13, Dopis pukovnika KNOJ-a Dušana Dotlića Ministarstvu inostranih poslova FNRJ, br. 12697, 26. 10. 1946.

${ }^{31}$ DA MSP, PA, Jugoslavija, 1946, fasc. 47, dos. 13, Dopis pukovnika KNOJ-a Dušana Dotlića Ministarstvu inostranih poslova FNRJ, br. 15090, 20. 12. 1946.

32 DA MSP, PA, Rumunija, 1946, fasc. 76, dos. 11, Dopis OZNA-e - Ministarstvu inostranih poslova DFJ, br. 1999, 22. 2. 1946. 
ne jugoslovenski graničari su ubili dvojicu rumunskih državljana koji su bili službenici Đerdapske administracije, na šta je Rumunija uložila protestnu notu a Jugoslavija obećala sprovođenje istrage. ${ }^{33}$ Incidentne situacije, koje su često zahtevale i diplomatske intervencije, događale su se ne samo na graničnoj liniji već i nešto dublje unutar rumunske teritorije, naročito na železničkoj pruzi od Vršca do Temišvara. Vozovima koji su saobraćali tom prugom kretalo se mnoštvo jugoslovenskih službenih lica koja su poslom putovala u Rumuniju, počev od diplomatskih kurira do naoružanih vojnika koji su predstavljali pratnju tokom transporta robe, što samo po sebi govori o prilikama koje su tih godina vladale na tamošnjim prugama. Dvojica takvih naoružanih boraca koji su pripadali samostalnom vodu pri delegaciji Jugopetrola u Ploeštiju napadnuti su na železničkoj stanici u Temišvaru 29. juna 1947. godine. Jedan od njih je u samoodbrani udario rumunskog konduktera kundakom po glavi što je izazvalo intervenciju desetak rumunskih žandarma, došlo je do pucanja u vazduh, a epilog je bio neveseo za Jugoslovene koji su, pretučeni, završili u bolnici. ${ }^{34}$ Samo nekoliko dana kasnije, 3. jula, napadnut je drugi vojnik kome je oduzet šinjel na šta je on repetirao automatsku pušku i, poučen iskustvom dvojice kolega, sklonio se u čekaonicu na železničkoj stanici u Temišvaru koja je bila rezervisana za sovjetske vojnike. Odatle je, u pratnji jednog sovjetskog službenika koji mu je garantovao bezbednost, otputovao za Ploešti. ${ }^{35}$ Isti vojnik, dve nedelje kasnije u povratku iz Ploeštija doživeo je da bude i opljačkan kada mu je ukradeno čak 5,5 miliona leja i vojna knjižica. U proleće 1948. godine dogodio se čitav niz incidenata u kojima su žrtve bili uglavnom diplomatski kuriri jugoslovenskog MIP-a i predstavnici raznih jugoslovenskih preduzeća. Svi ti incidenti dogodili su se u pograničnoj železničkoj stanici Žombolj (rum. Jimbolia) tokom aprila i svima im je bilo zajedničko da su rumunske službe bezbednosti na železničkoj stanici zadržavali kurire koji su imali sve potrebne vize i dozvole dok ne dobiju odobrenje za njihov ulazak u zemlju direktno iz Bukurešta. ${ }^{36}$ Kako je to iziskivalo određeno vreme, voz kojim su bili doputovali bi otišao a kuriri prisiljeni da čekaju i po 24 sata na sledeći voz. Tih dana dogodilo se i da jednoj grupi omladinaca srpske nacionalnosti, koji su bili rumunski državljani, ne bude dozvoljeno da otputuju za Jugoslaviju gde su želeli da učestvuju na izgradnji autoputa Beograd-Zagreb, pod izgovorom da nose previše prtljaga. ${ }^{37}$ Ovaj niz događaja dva meseca pred objavljivanje Rezolucije Informbiroa ukazuje da su jugoslovensko-rumunski odnosi već tada krenuli nizbrdo, mada u to vreme zakulisno i tek kao najava otvorenog sukoba koji će uslediti u narednim godinama.

${ }^{33}$ DA MSP, PA, Rumunija, 1947, fasc. 103, dos. 5, Zabeleška o razgovoru druga Velebita, pom. ministra inostranih poslova, sa rumunskim ambasadorom Vijanu-om na dan 3. 10. 1947. u 18 časova, br. 427556.

${ }^{34}$ DA MSP, PA, Rumunija, 1947, fasc. 103, dos. 4, Izveštaj o incidentima i prekršajima II uprave Generalštaba JA, br. 413841, 21. 7. 1947.

${ }^{35}$ Isto.

${ }^{36}$ DA MSP, PA, Jugoslavija, 1948, fasc. 91, dos. 1, Dopis načelnika III regionalnog odeljenja MIP FNRJ D. Đurđeva - ambasadi FNRJ u Bukureštu, br. 412192, 6. 5. 1948, 1-2.

${ }^{37}$ Isto, 2. 
Česti incidenti i neovlašćeni prelasci jugoslovensko-rumunske granice učinili su da u obe zemlje sazri svest da je neophodno urediti pogranični režim tako da bude efikasniji, za šta je bilo neophodno i unapređenje infrastrukture na granici. Na predlog Rumunije, Jugoslavija je 1947. prihvatila da se iste godine izvrši revizija svih graničnih oznaka na jugoslovensko-rumunskoj graničnoj liniji. $^{38} \mathrm{U}$ tom cilju, formirana je mešovita jugoslovensko-rumunska komisija za pregled i obnovu graničnih stubova koja je započela rad sastankom u Temišvaru 23. i 24. septembra kada je utvrđen plan aktivnosti, da bi od 25. septembra počeo rad na terenu obilaskom oznaka duž granične linije, počev od tromeđe Jugoslavije, Rumunije i Mađarske ka jugu. ${ }^{39}$ Pregovori u Temišvaru i rad na terenu odvijali su se u prijateljskoj atmosferi, jugoslovenska delegacija je svuda bila primljena sa uvažavanjem, počev od rumunskih vojnih i civilnih vlasti u Temišvaru do lokalnog stanovništva duž granice. Na samoj graničnoj liniji komisija je primetila da nedostaje tek neznatan broj stubova, ali je zato zatekla veliki broj njih kojima je bila neophodna popravka - od učvršćivanja, ispravljanja do promene natpisa „SHS“ ili „J“ u „FNRJ“ što je bila posledica nedavnog rata tokom koga granični stubovi nisu održavani, ali i promene zvaničnog imena jugoslovenske države. ${ }^{40}$

Jedino pitanje koje nije moglo biti rešeno u okviru komisije bilo je vezano za granični kamen na tromeđi Jugoslavije, Rumunije i Mađarske i to stoga što je imalo dugu predistoriju. Suštinu problema predstavljala je činjenica da se granični stub koji je označavao jugoslovensko-rumunsko-mađarsku tromeđu nije nalazio na mestu koje je odredila Mirovna konferencija u Versaju (i Trijanonski ugovor koji je potpisala Mađarska) već 12,5 kilometara severoistočno idući uz granicu Rumunije i Mađarske. To je bila posledica naknadne razmene teritorija između Kraljevine SHS i Rumunije, odnosno odricanja Kraljevine SHS od sela Stara Beba u korist Rumunije, što je ušlo i u konačni Sporazum o definitivnom razgraničenju potpisan 24 . novembra 1923 . godine. ${ }^{41}$ Iako to nije diralo u mađarsku teritoriju, Mađarska je odbijala da prihvati takvo pomeranje tromeđe pa su Kraljevina SHS i Rumunija 4. jula 1927, da bi legalizovale nastalu promenu, potpisale poseban protokol kojim je Rumunija na 99 godina ustupila koridor širine 1 metra duž tih 12,5 kilometara rumunsko-mađarske granice kako bi tromeđa mogla da ostane na onom mestu gde su je odredile Kraljevina SHS i Rumunija. ${ }^{42}$ Posle Drugog svetskog rata, međutim, u mirovnom ugovoru iz Pariza koji su potpisale i Mađarska i Rumunija navedeno je da je njihova granica istovetna onoj iz 1938. godine iz čega su u Rumuniji izvodili zaključak da se Mađarska samim tim saglasila sa tromeđom koju su odredile Kraljevina SHS i Rumunija, sa čime se u Jugo-

${ }^{38}$ DA MSP, PA, Rumunija, 1947, fasc. 103, dos. 7, Dopis pomoćnika načelnika I regionalnog odeljenja MIP FNRJ Blagoja Hadži-Panzova - Generalštabu JA, br. 410046, 9. 7. 1947.

${ }^{39}$ DA MSP, PA, Rumunija, 1947, fasc. 103, dos. 7, Izveštaj majora Arsenija Jankovića, šefa jugoslovenske delegacije u mešovitoj jugoslovensko-rumunskoj komisiji za razgraničenje - I regionalnom odeljenju MIP FNRJ, br. 419380, 1. 10. 1947.

${ }^{40}$ Isto, $1-2$.

${ }^{41}$ G. Popi, $n$. d., 53-54.

42 DA MSP, PA, Rumunija, 1947, fasc. 103, dos. 8, Referat o pitanju jugoslovensko-rumunskomađarske tromeđe, br. 420468, 2. 2. 1948. 
slaviji nisu slagali zahtevajući da Rumunija obezbedi i formalnu saglasnost Mađarske. ${ }^{43}$ Iz tog razloga, pitanje definitivnog mesta na kome će stajati granični kamen na tromeđi Jugoslavije, Rumunije i Mađarske ostalo je otvoreno.

Povlačenjem granice između Kraljevine SHS i Rumunije posle Prvog svetskog rata podeljena je do tada jedinstvena teritorija Banata, što je u selima uz granicu dovelo do pojave da jedan broj građana bude nastanjen sa jedne strane granice, a njihova imanja budu sa druge strane. Za te ljude uređen režim prelaska jugoslovensko-rumunske granice bio je nasušna potreba, jer je od obrade zemlje zavisila njihova egzistencija. Kao rešenje, u međuratnom periodu je između Kraljevine SHS/Jugoslavije i Rumunije uspostavljen dvovlasnički režim kojim je građanima obe zemlje bilo omogućeno da prelaze granicu radi obrađivanja imanja u susednoj zemlji. To pitanje regulisala je i posebna Konvencija o režimu pograničnih imanja koja je zaključena između dveju susednih zemalja 30. januara 1923, a zatim potvrđena i Konvencijom o pograničnom prometu od 5. jula 1924. godine. ${ }^{44}$ Konvencija je primenjivana do aprila 1941 , to jest do nemačke okupacije Jugoslavije, da bi nove okolnosti koje su nastupile ponovnim zaposedanjem Banata od strane jugoslovenske vojske u zimu 1944/1945. godine, kao i posledice rata koji je tada još uvek trajao, donele brojne izazove u funkcionisanju dvovlasničkog režima na jugoslovenskorumunskoj granici. Te nove okolnosti bile su oličene u dolasku Crvene armije u Rumuniju koja je posle kapitulacije 23. avgusta 1944. prihvatila okupaciju saveznika, ali i u promenjenom statusu banatskih Nemaca (tzv. folksdojčera) koji su zbog svoje uloge tokom prethodnog rata postali nepoželjni u obe zemlje, a naročito u Jugoslaviji. ${ }^{45}$ Dolazak sovjetskih okupacionih vlasti promenio je situaciju na jugoslovensko-rumunskoj granici tako što su lokalne sovjetske komande, pored jugoslovenskih i rumunskih pograničnih vlasti, sada predstavljale još jednu instancu koja je kontrolisala prelazak granice. To je dovelo do toga da su aprila 1945. godine, dok je rat još trajao, jugoslovenski državljani morali da pored davanja podataka o sebi i svrsi puta kao i o mestu prelaska granice dobiju prvo rumunsko odobrenje, a rumunske vlasti potom sovjetsko odobrenje svoje odluke, da bi mogli da pređu granicu. ${ }^{46}$ Ovakav režim prelaska granice gotovo je obesmišljavao dvovlasnički sistem koji je bio ustanovljen pre rata. S druge strane, banatski Nemci koji su predstavljali dobar deo dvovlasnika, tačnije jedan broj njih koji je ostao na svojim imanjima pošto je većina izbegla sa nemačkom vojskom u jesen 1944. godine, posmatrani su u Jugoslaviji kao neprijatelji, bez obzira na to da li su bili jugoslovenski ili rumunski državljani, što je imalo značajne posledice po njihova prava na prelazak granice po predratnoj jugoslovensko-rumunskoj konvenciji.

${ }^{43}$ Isto, 2.

${ }^{44}$ G. Popi, n. d., 59.

${ }^{45}$ Više o tome u: Zoran Janjetović, Deca careva, pastorčad kraljeva: nacionalne manjine u Jugoslaviji 1918-1941 (Beograd: Institut za noviju istoriju Srbije, 2005); Zoran Janjetović, Nemci u Vojvodini (Beograd: Institut za noviju istoriju Srbije, 2009).

${ }^{46}$ DA MSP, PA, Jugoslavija, 1945, fasc. 20, dos. 17, Depeša Predstavništva DFJ u Bukureštu V. Velebitu, br. 619, 25. 4. 1945. 
Već u to vreme, u jesen 1944. godine, došlo je do prvih problema u funkcionisanju dvovlasničkog režima kada su u pitanju bili Nemci - rumunski državljani. Jedan broj njih koji su živeli na potezu carinarnica Kručeni (rum. Cruceni) - Jaša Tomić sprečile su jugoslovenske vlasti da pređu granicu čime je 327 katastarskih jutara koje su posedovali ostalo neobrađeno. ${ }^{47}$ Nešto kasnije, u leto 1945. godine, rumunska vlada se preko Diplomatskog predstavništva DFJ u Bukureštu žalila na postupke jugoslovenskog komandanta pograničnog sektora naspram rumunske varošice Žombolj; on je, prethodno boraveći tamo sa jednom delegacijom, obavestio rumunsku stranu da će dvovlasnici sa rumunske teritorije moći da pređu na jugoslovensku tek pošto se utvrdi njihova etnička pripadnost. ${ }^{48}$ Iako ne navodeći da se u stvari radilo o sprečavanju Nemaca da obrađuju svoja imanja, rumunske vlasti su tvrdile da je ta mera nanosila ogromne štete $i$ tražile da se ona ukine. ${ }^{49}$ Ta mera je, međutim, bila posledica odluke donete na najvišem nivou - 26. novembra 1944. AVNOJ je doneo Odluku o prelasku neprijateljske imovine $u$ državnu svojinu, kojom je konfiskovana i imovina rumunskih državljana nemačke nacionalnosti koja se nalazila na teritoriji Jugoslavije. ${ }^{50}$ Ova odluka je kasnije potvrđena posebnim Zakonom o potvrdi $i$ izmenama odluke o prelazu u državnu svojinu neprijateljske imovine od 31. jula 1946. čime su imanja rumunskih državljana nemačke nacionalnosti potom uključena u agrarni fond NR Srbije i dodeljivana u vlasništvo agrarnim interesentima, $u$ skladu sa jugoslovenskim zakonom o agrarnoj reformi i kolonizaciji. Logična posledica konfiskacije bila je i promena statusa Nemaca iz Rumunije koji posle nje, za jugoslovenske vlasti, više nisu ni bili smatrani dvovlasnicima te im zato nije ni bio omogućen prelaz na jugoslovensku teritoriju po tom osnovu. ${ }^{51} \breve{S t a v i-}^{-}$ še, na osnovu istih zakonskih propisa Jugoslavija je konfiskovala i imovinu jugoslovenskih državljana nemačke nacionalnosti koja se nalazila na teritoriji Rumunije i predala je na korišćenje Upravi narodnih dobara.

Kao odgovor na ove jugoslovenske mere, u jesen 1945. godine rumunske vlasti su počele da ometaju prelazak granice jugoslovenskim dvovlasnicima pravdajući to reciprocitetom zbog zabrane prelaska njihovim državljanima nemačke nacionalnosti. ${ }^{52}$ Rumunske pogranične vlasti su, međutim, ometale prelazak svih jugoslovenskih dvovlasnika, bez razlike da li se radilo o Nemcima ili ne, što je u pojedinim slučajevima dovodilo do ozbiljnih pograničnih incidenata. Tako je jedna jugoslovenska državljanka koja nije bila Nemica, radeći na svom

${ }^{47}$ DA MSP, PA, Rumunija, 1947, fasc. 102, dos. 16, Dopis Ministarstva inostranih poslova FNRJ - Ministarstvu unutrašnjih poslova FNRJ, 57840, 27. 5. 1947.

${ }^{48}$ AJ, 50-64-138, Dopis načelnika Političkog odeljenja Ministarstva inostranih poslova DFJ Jože Brileja - Predsedništvu Ministarskog saveta DFJ, br. 4300, 22. 8. 1945.

${ }^{49}$ Isto.

${ }^{50}$ DA MSP, PA, Rumunija, 1947, fasc. 102, dos. 16, Dopis načelnika Ministarstva unutrašnjih poslova FNRJ R. Radovića - Ministarstvu inostranih poslova FNRJ, br. 410649, 7. 6. 1947.

${ }^{51}$ Isto.

52 DA MSP, PA, Rumunija, 1945, fasc. 27, dos. 29, Dopis načelnika Političkog odeljenja Ministarstva inostranih poslova DFJ Jože Brileja - Predstavništvu DFJ u Bukureštu, br. 7610, 5.1. 1946. 
imanju zajedno sa očuhom i sestrom, bez ikakvog povoda na silu odvedena do rumunske karaule gde je pretučena da bi rumunski vojnici potom otvorili vatru na njenog očuha i sestru koji su počeli da beže što je, sa jugoslovenske strane, takođe izazvalo otvaranje vatre. ${ }^{53}$ Samo pukom srećom u toj razmeni vatre niko nije stradao. Početkom 1946. godine, jugoslovensko Ministarstvo inostranih poslova je preko svog predstavništva u Bukureštu uputilo Rumuniji objašnjenje svog stanovišta u vezi sa zabranom prelaska Nemaca dvovlasnika na jugoslovensku teritoriju. Ministarstvo je tvrdilo da je Jugoslavija 1945. godine načelno odlučila da rumunske dvovlasnike ne tretira različito u zavisnosti od njihove nacionalne pripadnosti, ali je i podsećalo rumunsku stranu da je na sastanku jugoslovenskih i rumunskih pograničnih organa 20. aprila 1945. dogovoreno da se neće dozvoljavati prelaz na jugoslovensku teritoriju onim rumunskim državljanima nemačke nacionalnosti koji su se tokom rata prema Jugoslaviji držali neprijateljski. ${ }^{54}$ Ukazujući na član 22 predratne konvencije koji je omogućavao da se pojedinim licima zabrani prelazak granice iz razloga nacionalne bezbednosti i javne sigurnosti, jugoslovenske vlasti su tvrdile da je bolje da takvim licima zabrane ulazak u zemlju nego da ih po njihovom ulasku gone i eventualno hapse zbog dela počinjenih tokom rata i tako dovedu do većih posledica po prijateljske odnose sa Rumunijom. Najzad, jugoslovenski MIP je bio izričit da Rumunija nema pravo da, pozivajući se na reciprocitet, zabranjuje jugoslovenskim dvovlasnicima prelazak granice. ${ }^{55}$

Rumunsko pozivanje na reciprocitet i prethodno potpisane konvencije imalo je za jugoslovensku stranu, osim značaja za konkretne slučajeve, i drugu dimenziju. Iako se i sama pozivala na njih, Jugoslavija je na sve te konvencije gledala kao na privremeno rešenje jer je njen principijelan stav, koji je moguće naći u više dokumenata, bio da su sve te konvencije i sporazumi prestale da važe činom ulaska Rumunije $u$ rat na strani sila Osovine te da sada, $u$ izmenjenim okolnostima, više ne odgovaraju jugoslovenskim interesima. ${ }^{56}$ Polazeći od toga, na konferenciji održanoj 10. avgusta 1946. predstavnici jugoslovenskog Ministarstva inostranih poslova, Ministarstva unutrašnjih poslova, Ministarstva narodne odbrane i Ministarstva finansija diskutovali su o svim problemima $u$ vezi sa pograničnim prometom sa Rumunijom i zaključili da sva pitanja, pa i pitanje dvovlasnika i rumunskih dvovlasnika nemačke nacionalnosti, treba i dalje rešavati privremeno. ${ }^{57}$ Takav pristup, međutim, nije doneo i rešenje pro-

${ }^{53}$ DA MSP, PA, Rumunija, 1945, fasc. 27, dos. 23, Izveštaj načelnika OZNA-e za Vojvodinu majora Radivoja Radovića - Ministarstvu narodne odbrane DFJ, br. 3319, bez datuma.

${ }^{54}$ DA MSP, PA, Rumunija, 1945, fasc. 27, dos. 29, Dopis načelnika Političkog odeljenja Ministarstva inostranih poslova DFJ Jože Brileja - Predstavništvu DFJ u Bukureštu, br. 7610, 5. 1. 1946.

${ }^{55}$ Isto, $1-2$.

${ }^{56}$ AJ, 50-64-138, Dopis Ministarstva inostranih poslova FNRJ - Predsedništvu vlade FNRJ, br. 8837, 3. 8. 1946.

57 Isto; AJ, 50-64-138, Depeša Predsedništva vlade FNRJ - Ministarstvu inostranih poslova FNRJ, br. 1166, 6. 8. 1946. Povremeni sastanci na kojima su jugoslovenske vlasti pokušavale da nađu sistemsko rešenje problema u funkcionisanju dvovlasničkog režima nisu bili potrebni 
blema. Naredne, 1947. godine, sa početkom poljoprivrednih radova ponovila se gotovo istovetna situacija. U martu je rumunska ambasada, pozivajući se ponovo na konvenciju iz 1924. godine, tražila od jugoslovenskih vlasti da obezbede propusnice za rumunske dvovlasnike kako bi mogli da obave neophodne poljo-

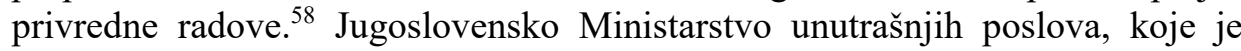
bilo nadležno za izdavanje pomenutih dozvola, držalo se stava da rumunski državljani nemačke nacionalnosti kojima je imovina konfiskovana više nisu dvovlasnici i da po tom osnovu ne mogu da dobiju stalne propusnice. ${ }^{59}$

Problemi u vezi sa funkcionisanjem dvovlasničkog režima na jugoslovensko-rumunskoj granici iznova su se pojavili i 1948. godine, opet u proleće. Pozivajući se na potrebu da se uklone prepreke koje su sprečavale normalnu obradu dvovlasničkih imanja i zaštite interesi dvovlasnika, Rumunija je notom posredstvom jugoslovenske ambasade u Bukureštu 14. aprila dostavila predlog formulara stalne dozvole za prelazak granice, kao i izvesne predloge da bi se $u$ načelu rešili problemi koji su se redovno pojavljivali. ${ }^{60}$ Deset dana kasnije usledila je još jedna intervencija rumunske strane, odnosno zahtev da se hitno odgovori na notu. Ministarstvo inostranih poslova u Beogradu predloge je prosledilo Ministarstvu unutrašnjih poslova, ali je ono tek 15. maja odgovorilo da se ne slaže sa rumunskim predlozima već da smatra da je najbolje organizovati sastanak sa predstavnicima nadležnih rumunskih vlasti na kome bi se našlo rešenje $i$ potpisao zajednički zapisnik koji bi potom odobrile obe vlade. Dve nedelje kasnije, 1. juna, tokom razgovora jugoslovenskog pomoćnika ministra inostranih poslova Gustava Vlahova i rumunskog ambasadora u Beogradu Teodora Rudenka zaključeno je da treba oformiti zajedničku komisiju koja bi se pozabavila problemom prelaska dvovlasnika preko granice s tim što je Rudenko tražio da se to pitanje u međuvremenu, dok se komisija ne sastane $\mathrm{i}$ ne donese neke zaključke, nekako privremeno uredi. ${ }^{61}$ Posle tog razgovora, usledila je rumunska nota od 24. juna kojom se Rumunija i zvanično saglasila sa formiranjem mešovite jugoslovensko-rumunske komisije i čak insistirala da se ona sastane odmah, predlažući Bukurešt kao mesto susreta.

Do tog susreta, međutim, nikada nije došlo. Samo četiri dana kasnije objavljena je Rezolucija Informbiroa sa teškim optužbama na račun Komunističke partije Jugoslavije i jugoslovenske politike uopšte koja je naglo pogoršala odnose Jugoslavije sa SSSR-om i zemljama „narodne demokratije“, a samim

samo zbog problema na granici prema Rumuniji već zato što ih je bilo i na granicama sa ostalim susedima. Više o tome u: Božica Slavković Mirić, „Pogranični promet Jugoslavije i Albanije i dvovlasnička imanja 1945-1948”, Istorija 20. veka, br. 1, (2020), 117-124.

${ }^{58}$ DA MSP, PA, Rumunija, 1947, fasc. 102, dos. 16, Dopis pomoćnika načelnika I regionalnog odeljenja Draga Govorušića - Komisiji za agrarnu reformu i kolonizaciju pri Vladi FNRJ, br. 44985, 28. 3. 1947.

${ }^{59}$ DA MSP, PA, Rumunija, 1947, fasc. 102, dos. 16, Dopis Ministarstva unutrašnjih poslova FNRJ - Ministarstvu inostranih poslova FNRJ, br. 12399, 7. 6. 1947.

${ }^{60}$ AJ, 50-64-138, Dopis III regionalnog odeljenja Ministarstva inostranih poslova FNRJ - Predsedništvu vlade FNRJ, br. 420203, 28. 7. 1948.

${ }^{61}$ Isto. 
tim i sa Rumunijom. To je dovelo do munjevitog i potpunog preokreta kada je $u$ pitanju bio stav Rumunije prema dvovlasničkom režimu na granici prema Jugoslaviji. Ambasador Rudenko je 17. jula ponovo razgovarao sa Vlahovom s tim što je ovog puta izjavio da je razmislio o njihovom ,,privatnom razgovoru“ od pre mesec i po dana i da je, kao i rumunska vlada, zaključio da je najbolje rešenje da dve zemlje razmene zemljište svojih građana u drugoj zemlji, odnosno da se dvovlasnički režim ukine. ${ }^{62}$ Vlahov je bio izuzetno nezadovoljan jer predmet njegovog razgovora sa Rudenkom 1. juna nije bila nikakva razmena zemljišta već mogućnost privremenog regulisanja prelaska dvovlasnika preko zajedničke granice. Iako je Rumunija predlog o ukidanju dvovlasničkog režima ponovila u pisanoj noti, jugoslovensko Ministarstvo inostranih poslova je ostalo pri stavu da je za rešavanje tog pitanja najbolje oformiti mešovitu jugoslovenskorumunsku komisiju koja bi našla sveobuhvatno rešenje. ${ }^{63}$ Pošto je ubrzo usledilo naglo pogoršanje međudržavnih odnosa Jugoslavije i Rumunije koje je obuhvatilo čak i potpuni prekid ekonomskih i kulturnih odnosa, železničkog i poštanskog saobraćaja, pitanje konačnog regulisanja dvovlasničkog režima ostalo je nerešeno i u narednim godinama.

Stanje koje je vladalo na granici između Jugoslavije i Rumunije dobar je pokazatelj uticaja promenjenih okolnosti na jugoslovensko-rumunske odnose. Iako su ti odnosi bili tradicionalno dobri i prijateljski, kakvim se mogu smatrati i u periodu 1945-1948. godine uprkos njihovom prekidu tokom Drugog svetskog rata zbog učešća Rumunije na strani sila Osovine, uočljivo je izvesno nepoverenje. Ono je bilo posledica različitog gledanja dveju zemalja na prisustvo sovjetskog faktora, ali i nesrazmerne brzine kojom je tekao proces pretvaranja obe susedne zemlje u državu tipa ,narodne demokratije“. Dok je u Jugoslaviji Crvena armija doživljavana kao oslobodilačka a proces sovjetizacije okončan veoma brzo, u Rumuniji je ista ta Crvena armija bila okupator a pomenuti proces tekao sporije i uz neuporedivo veće otpore. To je razlog zbog koga su rumunska vojska i administracija $\mathrm{u}$ to vreme u Jugoslaviji često posmatrane kao ostaci prethodnog, fašističkog režima ali i kao nosioci otpora sovjetizaciji, a sa druge strane Jugoslavija sa rumunskog stanovišta doživljavana kao saradnik i pomagač u Rumuniji neželjene Crvene armije. Na terenu, u ovom slučaju na jugoslovensko-rumunskoj granici, obostrano nepoverenje je bilo vidljivo kroz često odsustvo saradnje što je za posledicu imalo nesređeno stanje bezbednosti, povremene incidentne situacije i nefunkcionalan dvovlasnički režim.

\footnotetext{
62 Isto, 2.

${ }^{63}$ Isto.
} 


\section{REFERENCE}

- Cvetković, Vladimir Lj. „Crvena armija na Dunavu, oslobođenje Beograda i težnje Srba iz Rumunije ka prisajedinjenju Jugoslaviji 1944-1945”. U: Oslobođenje Beograda 1944. godine. Urednik Aleksandar Životić, 168-184. Beograd: Institut za noviju istoriju Srbije, 2010.

- Deletant, Dennis. Romania under Communist Rule. Bucharest: Civic Academy Foundation, 2006.

- Ionița, Gheorge I. Istoria românilor - de la 23 august 1944 până în prezent. București: Editura Universității din București, 2001.

- Janjetović, Zoran. Deca careva, pastorčad kraljeva: nacionalne manjine u Jugoslaviji 1918-1941. Beograd: Institut za noviju istoriju Srbije, 2005.

- Janjetović, Zoran. Nemci u Vojvodini. Beograd: Institut za noviju istoriju Srbije, 2009.

- Krizman, Bogdan. „Pitanje granica Vojvodine na Pariškoj međunarodnoj konferenciji 1919. godine (diplomatsko-historijska skica)“. Zbornik Matice srpske za društvene nauke, br. 24, (1959), 31-72.

- Milin Andrej, Miodrag Milin, i Cvetko Mihajlov. Srbi u Rumuniji za vreme komunizma. Zvučni arhiv i priručnik o stradanju. Temišvar: Savez Srba u Rumuniji, 2011.

- Milin Miodrag, i Andrej Milin. Srbi iz Rumunije i jugoslovensko-rumunski odnosi. Prilog i građa (1944-1948). Vršac: Viša škola za obrazovanje vaspitača, Temišvar: Univerzitet „Banatului“, 2004.

- Mitrović, Andrej. Jugoslavija na Konferenciji mira: 1919-1920. Beograd: Zavod za izdavanje udžbenika Socijalističke Republike Srbije, 1969.

- Mitrović, Andrej. Razgraničenje Jugoslavije sa Mađarskom i Rumunijom: 1919-1920: prilog proučavanja jugoslovenske politike na Konferenciji mira u Parizu. Novi Sad: Institut za izučavanje istorije Vojvodine, 1975.

- Petranović, Branko. „Pitanje granica Jugoslavije prema Mađarskoj i Rumuniji i jugoslovenskih manjina u Mađarskoj i Rumuniji posle Prvog i Drugog svetskog rata (istorijska paralela)“. Istorijski zapisi, XXXIX (LIX), br. 3, (1986), 107-117.

- Popi, Gligor. Jugoslovensko-rumunski odnosi 1918-1941. Novi Sad: Institut za istoriju Filozofskog fakulteta u Novom Sadu, 1984.

- Rădulescu-Zoner Șerban și Daniela Bușe și Beatrice Marinescu. Instaurarea totalitarismului comunist în România. București: Cavallioti, 2002.

- Slavković Mirić, Božica. „Pogranični promet Jugoslavije i Albanije i dvovlasnička imanja 1945-1948". Istorija 20. veka, br. 1, (2020), 117-124. https://doi.org/10.29362/ist20veka.2020.1.sla.107-128

- Stojanov, Pavle. Jugoslovenska nacionalna manjina u Rumuniji. Beograd: Kultura, 1953.

- Tasić, Dmitar. „Organizacija granične službe u jugoslovenskim oružanim snagama od kraja Drugog svetskog rata do rezolucije Informbiroa 1948. godine“. Vojnoistorijski glasnik, br. 1, (2014), 233-250. 
- Timofejev, Aleksej. „Iskustvo sučeljavanja: Crvenoarmejci i stanovništvo Srbije“. U: Oslobođenje Beograda 1944. Urednik Aleksandar Životić, 210236. Beograd: Institut za noviju istoriju Srbije, 2010.

VLADIMIR LJ. CVETKOVIĆ, PhD, Senior Research Associate Institute for Recent History of Serbia

Belgrade, Republic of Serbia

cvetkovicv@yahoo.com

\section{SITUATION ON YUGOSLAV-ROMANIAN BORDER AND TWO-OWNER ESTATES 1945-1948}

\section{Summary}

Based on Yugoslav archival sources and relevant literature, the paper examines the situation on the Yugoslav-Romanian border from the end of the World War II until the Cominform Resolution of June of 1948, which led to a deterioration of relations between the two states. By looking at threatening state of security at the border, border incidents, and the functioning of two-owner estates, it is possible to see the attitude and policy of Yugoslavia toward Romania and events on its political scene during its transformation from a parliamentary monarchy to a one-party Soviet-type republic. The situation on the border between Yugoslavia and Romania is a good indicator of the impact of changed circumstances on Yugoslav-Romanian relations. Although these relations were traditionally friendly, as they had been in the period between 1945 and 1948, despite their interruption during World War II due to Romania's siding with the Axis, some distrust was noticeable. It was a consequence of the two countries' different view on the presence of the Soviet factor, but also of the disproportionate speed with which the process of transforming both states into people's democracies proceeded. Whereas Yugoslavia viewed the Red Army as a liberator and the process of Sovietization was finished quickly, in Romania the same Red Army was seen as an occupier and the mentioned process was slower with incomparably greater resistance. This is because the Romanian Army and government administration were often seen as remnants of the previous fascist regime and elements of resistance to Sovietization in Romania at the time. On the other hand, from the Romanian point of view, Yugoslavia was perceived as a collaborator and helper of the unwanted Red Army in Romania. On the Yugoslav-Romanian border mutual distrust and lack of cooperation was present, which resulted in security issues, occasional incidents, and non-functioning of two-owner estates.

KEYWORDS: Yugoslavia, Romania, Two-Owner Estates, Border Incidents, Sovietization 